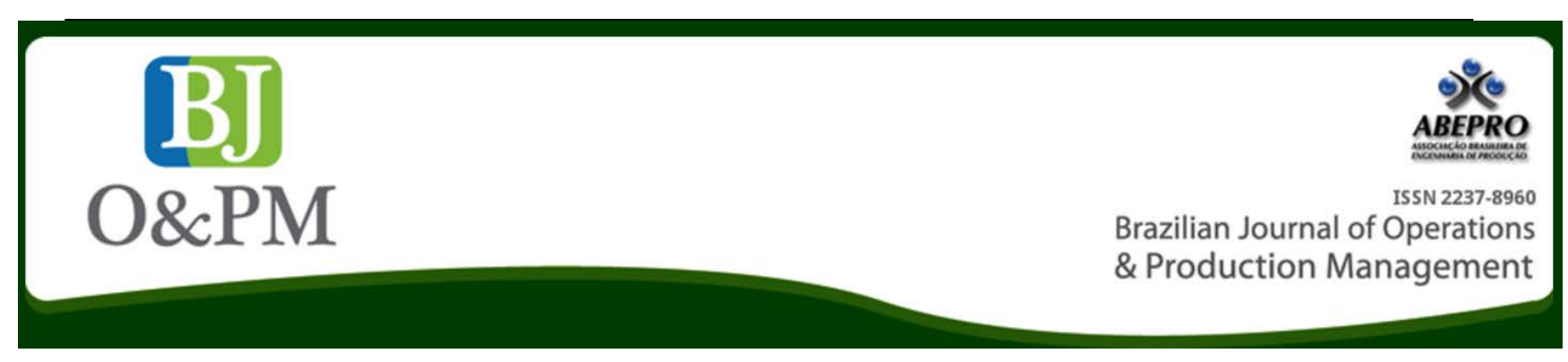

\title{
SUPPLY INDUSTRY DYNAMICS FOR BRAZILIAN SUGARCANE
}

\author{
Lara Bartocci Liboni Amuia; Rudinei Toledo Juniora; Michelle de Castro Carrijo ${ }^{\mathrm{b}}$; Luciana Oranges Cezarino \\ a University of São Paulo (USP), São Paulo, SP, Brazil \\ ${ }^{b}$ University of Uberlândia (USP), Uberlândia, MG, Brazil
}

\begin{abstract}
Sugarcane industry in Brazil is highly competitive in the production of ethanol, sugar and energy. This industrial competitiveness was also achieved through the development of the equipment involved in the production processes. The industry that supplies the equipment plays an important role in the competitiveness of sugarcane sector. This study seeks to analyze the organization and configuration of the equipment supply industries for sugar, ethanol and energy mills in Brazil. The study seeks to evaluate how innovation occurs in this sector, contributing to an important discussion about maintaining competitiveness and proposing a typology for this industry. The study is based on an analysis of information obtained through a set of interviews with leaders and entrepreneurs in the industry. The results allow us to conclude that the growing modernization of the sector will require greater efforts from the equipment industry to provide plants with necessary technological innovations and possible efficiency gains.
\end{abstract}

Keywords: Supplier Management; Industrial Supplier; Sustainability.

\section{INTRODUCTION AND METHODS}

Understanding the competitiveness of the sugarcane and energy industry is of fundamental importance for Brazil, not only because it is an activity that the country has dominated for centuries but also because the industry has obtained major gains in productivity and efficiency, becoming one of the most competitive agro-industrial activities in Brazil. The industry's development has been aided by a combination of good soil and climate conditions and a series of well-defined public policies throughout the industry's history that resulted in a large increase in the number of plants in the 1970s and 1980s and strengthened suppliers of machines and equipment for the mills. As a result, in addition to agricultural competitiveness, the sugarcane industry is also highly competitive in the production of ethanol, sugar, and energy. This industrial competitiveness has been achieved by developing both productive processes and the equipment involved in these processes. As such, the equipment supply industry has made important contributions to the sugarcane industry's competitiveness. Both the arrangement of the equipment supply industry and its experience have been determinant factors so that its competitiveness permeated ABEPRO DOI: 10.14488/BJOPM.2015.v12.n2.a5 the industry as a whole. The industry is characterized as essentially national capital and is strongly concentrated in the state of São Paulo.

The sugarcane industry's leading products are sugar, ethanol, and, more recently, electric energy. It is a very traditional industrial sector in the Brazilian economy, dating back to the colonial period and has remained one of the main industries in the country in terms of share of GDP, employment generation, and international integration (Sugarcane Industry Association - UNICA, 2010). In recent years, the sector has expanded due to continuous growth in the production of alcohol, sugar, and sugarcane. Ethanol production jumped from 11 billion liters in 2001/2002 to 27 billion liters in 2008/2009; during the same period, sugar rose from 19 million tons to 31 million tons, and the production of sugarcane grew from 300 million tons to 570 million tons (UNICA, 2009).

Power plants (or industrial plants) have a set of equipment for each of the stages of extraction, treatment, fermentation, and distillation, in addition to equipment for energy production, the transportation of raw materials, and the procurement of water and water treatment, among others. Productivity in the industrial stage depends on both the development of capital goods in different stages of the 
production process and engineering projects to integrate different components in the plant. The industry is comprised of some companies that design the plant as a whole and a large set of companies that develop different machines, equipment, and components (Sugarcane Equipment Industry Association of Sertãozinho - CEISE, 2009).

The technology for the supply of capital goods for plants is essentially national. The sector is dominated by national companies with low level of imports and foreign capital. The industry is located primarily in the regions of Piracicaba and Sertãozinho, in the state of São Paulo, and features industrial agglomerations, particularly in the mechanical and metallurgical sectors. The industry's organization is different in each region, both in relation to the degree of integration and the size of the companies and their strategies. This type of industrial organization, in the form of local production arrangements, contributes to greater efficiency in the sector and greater dynamism for the regions in which they are located (CEISE, 2009).

A number of questions arise in relation to the industry's performance, including: what is the equipment supply industry's ability to keep up with the demand generated by the sugarcane industry's expansion, and how does innovation occur in these industries? This study seeks to answer these questions by assessing some of the characteristics of these industrial agglomerations and proposing a typology for the industries.

The qualitative research is based on a set of non-structured interviews conducted in 2011 with representatives and experts from the industry: Adésio José Marques of the Sertãozinho Center for Industries (Sugarcane Equipment Industry Association of Sertãozinho - CEISE); Octávio Valseschi, Coordinator of Master Technology Administration for Sugarcane Industry - MTA at the Federal University of São Carlos (São Carlos Federal University - UFSCAR); Antônio de Pádua of the Sugarcane Industry Union (Sugarcane Industry Association - UNICA); José Luiz Olivério of Dedini ${ }^{1}$; Luis Biagi of Renk Zanini²; and Marco Pastorelli of Unisystems ${ }^{3}$.

\footnotetext{
${ }^{1}$ Dedini- Operates in the sugar and ethanol with expertise in technology for high efficiency, with own manufacturing and embedded systems, provides individual equip ment or under "turnkey", from receipt, preparation, extraction and treatment of the broth to produce sugar and ethanol.

${ }^{2}$ Renk Zanini- The consolidation of its brand began in 1976 with the merger of Zanin S.A. Equipamentos Pesados from Sertãozinho (SP) and Renk AG of Germany. Its purpose has been, since then, the production and sale of special, custom-built speed reducers, power transmission elements, and the provision of machining and Heat Treatment services. Its main office today is located in the State of São Paulo.

${ }^{3}$ Unisystems - Was established in 1995, in Miami (Florida), focused on supplying ad vanced technologies, engineering services and a large selection of sophisticated equipments of process for the sectors of sugar, ethanol and energy.In 1996 it was founded the Uni-Systems do Brasil hosted in Sertãozinho- São Paulo, focused on providing inte grated solutions of process and engineering services for the same industrial sectors.
}

The choice of method is justified by the need to obtain a generalized view of the organization and configuration of the equipment industry in the sugarcane sector. Secondary data were also used, which were acquired from databases such as the Sugarcane Industry Association (UNICA), the Brazilian Association of Machinery and Equipment Industry (ABIMAQ), the Brazilian Institute of Geography and Statistics (Instituto Brasileiro de Geografia e Estatística - IBGE), and the Annual List of Social Information (Relação Anual de Informações Sociais - RAIS). The instrument for data analysis was content analysis, which used to understand the information and systematize the knowledge acquired during the interviews.

\section{LOCAL PRODUCTION ARRANGEMENTS}

The debate over the issue of industrial clusters is an old one in the Brazilian economy, both for evaluating the determinants of agglomerations and verifying their impact in terms of competitiveness, the introduction and development of technological innovations, and the impact on regional development, among other aspects. The literature on local production arrangements (LPAs), defined as a geographic and sectoral concentration of small and medium enterprises that maintain a systematic relationship, spans various fields of the economy: the industrial economy, the technology economy, the regional and urban economy, and other areas that seek to analyze specific impacts from the presence of LPAs (Telles et Toneto Jr, 2007).

In his Principles of Economics, Marshall (1920) highlighted the idea that external economies that originate from the agglomeration of certain economic activities can enable efficiency gains for participants by attracting suppliers, making skilled labor easily available, or by other means. "External economies depend on the general development of the industry [...] and they can frequently be achieved through the concentration of many similar companies in certain places; or, as is often said, by the industry's location." (Marshall 1996, p. 315).

Therefore, the main advantages of the geographic and sectoral concentration of companies are the presence of external economies and the possibilities for joint strategies, which may be an important source of generating competitive advantages for business clusters (IPT, 2008). These joint strategies depend on local agents (companies and institutions) that are able to stimulate their competitive abilities through cooperative actions such as professional training, the creation of export consortia, contracting specialized services, and establishing collective technological centers. The union of incidental external economies with 
those obtained through deliberate joint actions results in a "collective efficiency", which determines the competitive capacity of the local companies (Schmitz et Nadvi, 1999 cited in Suzigan, et al., 2003).

A priori, the advantages of geographic and sectoral concentration result from the installation of supplier companies in the region, the provision of collective goods, specialization of local skilled labor, tacit knowledge that is created from the sector, and knowledge about what each firm is producing. Furthermore, as mentioned previously, the advantages of the companies' geographic and sectoral concentration can be enhanced by the companies' proactive behavior in organizing themselves, thereby creating power in negotiations with suppliers, making room for joint investments in research, developing strategies for access to foreign markets, and encouraging close relationships with universities, public bodies, etc. These arrangements can elevate the competitive condition of firms by obtaining efficiency gains from acting as a group (Telles et Toneto Jr, 2007).

LPAs are important for the development organizations, and they can influence economic and social development both regionally and nationally (Vicari, 2009; Jauhar, 2008). The challenges of economic growth and the need for more equitable socioeconomic development between regions have led the Brazilian federal government and state governments to encourage the organization of LPAs in various regions of the country. The organization of local industries through LPAs is part of the industrial policy guidelines set by the Brazilian Ministry of Development, Industry, and Foreign Trade (Telles et Toneto Jr, 2007).

LPAs can be described as a cluster of firms in a certain production chain in the same territory or region. More specifically, an LPA is a type of local production system with a geographic and sectoral concentration, generally of smalland medium-sized enterprises, that maintain a systematic relationship. The cluster can consist of companies that manufacture traditional, low-technology products or technology-based companies (Suzigan, et al., 2003).

For Cassiolato et Lastres (2003, p. 3, 4), LPAs are local clusters that focus on activities in a specific economic segment and rely on the involvement of economic, political, and social actors. The companies within the clusters have ties to each other, even if they are recent. These local clusters demonstrate participation and interaction between companies that produce capital goods, provide services, supply inputs, and market the cluster's products. They are also related to public and private organizations that support the cluster's activities, such as financial companies, political entities, marketing companies, research and development organizations, universities, and other entities for obtaining and training qualified labor.
LPAs have some degree of specialization in one or more of the links on the chain, such as improving production processes, developing new products, differentiating the design, managing storage logistics, and developing efficient distribution channels. All of the agents involved in the productive and commercial process benefit from these differentials, which are the result of maintaining a healthy, permanent interaction between the economic and social actors (Plonsky, Serra et Zenha, 2005).

Cooperation, regardless of the type of LPA, allows individual companies to operate at levels of efficiency and productivity that would not otherwise be achievable. Through interaction networks that are retro-feeding, the physical proximity between companies and institutions in an LPA fosters, facilitates, and increases the exchange of tangible assets - final and intermediate goods and services - and the diffusion of intangible assets such as relevant knowledge for the business (Plonsky, Serra et Zenha, 2005).

Telles et Toneto Jr. (2007) note that cooperation between firms can play a fundamental role in the process of innovation by increasing competitive capacity, mainly when small firms are competing with large firms, thereby creating greater capacity for investment and greater diffusion of knowledge. LPAs can thus encourage the emergence of regional systems of innovation in places they are located.

LPAs can be classified according to their degree of organization: (i) informal, (ii) organized, and (iii) innovative. This classification is based on the market structure, degree of technological development, level of articulation, and the size of the companies (Mytelka et Farinelli, 2005 cited in Plonsky, Serra et Zenha, 2005).

Plonsky, Serra et Zenha (2005) argue that the companies in an informal LPA produce homogeneous or slightly differentiated goods, developed with widely available technology. These companies require low levels of investment and show reduced barriers to entry and exit. They also show nascent expertise in management, a reduced level of technological development, and little cooperation between the companies in the cluster and with local actors such as clients. These companies adopt survival strategies for the markets in which they operate. In an organized LPA, the companies are more heterogeneous in terms of size, organizational structure, and strategic capacity. They also tend to be more specialized, producing differentiated or slightly differentiated goods. Their level of industrial investment is more robust, creating stronger barriers to entry. In addition, they employ more sophisticated management strategies and use relatively modern, but accessible, equipment and technology. They show some level of cooperation. In the innovative LPA, there are small, medium, and large businesses organized hierarchically. The small and medium enterprises gravitate around the large 
firms, which act as suppliers. They generally have a higher level of managerial, financial, and commercial expertise, in addition to skilled professionals. In this type of LPA, the capacity to innovate is strategic and cooperation is intense.

Definitions and typologies of LPAs are widely studied in the national and international literature. The literature is vast and, in some cases, contradictory (Suzigan, et al., 2003). Many studies focus on defining an LPA and differentiating it from other arrangements.

In the present study, the term LPA is used in accordance with Cassiolato et Lastres (2004), who believe that these arrangements do not show significant links between agents (nascent cooperation) and that they therefore cannot be characterized as systems (Cassiolato et Lastres, 2004). The authors use the term Local Productive and Innovative Systems (Sistemas Produtivos e Inovativos Locais - SPILs) to define "arrangements where interdependence, links, and consistent ties result in interaction, cooperation, and learning, with the potential to generate increased endogenous innovative capacity, competitiveness, and local development".

Thus, machine and equipment industry clusters for the sugarcane sector are considered LPAs and deserve note for their capacity and potential to generate competitiveness and innovation.

\section{RESULTS}

\subsection{The Equipment Industry for the Sugarcane Sector}

The capital goods sector in Brazil is responsible for the production of a complex set of machines and equipment used in the production of other goods. It thereby maintains a direct relationship with other sectors in addition to playing an important role in the diffusion and generation of new technologies (Brazilian Institute of Geography and Statistics - IBGE, 2010).

This sector consists of the following groups, according to the National Classification of Economic Activities: machines and equipment; motor vehicles, trailers and car bodies; other transportation equipment, which includes the aeronautical segment; machinery, appliances, and electrical equipment; communications equipment; medical equipment and instruments, precision instruments, and equipment for industrial automation; and office machines and information equipment (IBGE, 2010).

The most important segment in the capital goods industry, the industry of machines and equipment, is located mainly in the state of São Paulo. Brazil has an industrial park for producing machines and equipment that is strongly tied to the sugarcane agro-industry. The machines and equipment industry allowed the expansion and improvement of the production of sugar and ethanol (Brazilian Association of Machinery and Equipment Industry -ABIMAQ, 2010).

The industry of machines and equipment, tied to the sugarcane industry, is well developed in the country and is very important to the sugarcane sector's competitiveness. The sugarcane sector is also located mainly in the state of São Paulo, which contains a strong concentration of plants in the central-south region and the country's main industrial park, resulting in a concentration of sectors with high technological intensity, major research centers, and skilledlabor training.

The expansion of sugarcane cultivation in Brazil created strong incentives for the machines and equipment industries related to the sector. In addition to the demand associated with new plants, there was also a significant growth in demand to replace old equipment with more modern equipment. This replacement of equipment enabled the expansion of productivity and energy efficiency and allowed for the sale of surpluses.

The expansion of the sugarcane industry and the consequent increase in demand in the machines and equipment industries resulted in the entry of new actors in the sector, including foreign capital in a sector traditionally dominated by national capital (CEISE, 2009).

In the state of São Paulo, where most of the equipment industries for this sector is located, there are two regional production hubs: Piracicaba and Sertãozinho. These hubs historically developed with the presence of family businesses, which grew and stimulated the development of suppliers and competitors in the region.

The equipment industry in these cities is focused on the mechanical and metallurgical sectors. In Sertãozinho, the industry is strongly related to the sugarcane sector, with the predominant production of boilers and general purpose machinery. In Piracicaba, the industry is much more diverse.

Since 1940, two major metallurgical enterprises have specialized in manufacturing machinery and plants, and they stand out in this sector: Dedini, in Piracicaba, SP, and Zanini, in Sertãozinho, SP. These enterprises experienced a major expansion during the National Alcohol Program - Proalcohol. The main Brazilian suppliers produced approximately 200 independent distilleries (and 200 corresponding cogeneration plants). The two biggest manufacturers (Dedini et Zanini) produced, considering the production peaks, 96 million suits in one year, eighty-one distilleries in one year, and an average of sixty-three boilers per year between 1973 and 1982 (Macedo et Nogueira, 2004). The best phase for this sector was during Pro-alcohol, when these companies engaged a significant amount of employees and operated virtually full time. 
Dedini S.A. Basic Industries, the main company in the sector, is the result of the consolidation of the activities of Dedini, Zanini, Badoni, and Codistil (according to Dedini, 2007). The company has a market share in the sugarcane industry above $50 \%$ and has factories in Piracicaba, Sertãozinho, Recife, and Macéio. In addition to the sugarcane industry, it acts in other diverse sectors, including beer, biodiesel, and hydroelectric plants, among others. Dedini's main focus, however, is the sugarcane industry, where it produces technology for the production of sugar and hydrated and anhydrous alcohol and brandy, as well as machinery for sugar refineries, cogeneration plants, plants for tanks, and breweries, among others. Dedini also licenses technology for use in breweries, filtration systems, small central hydroelectrics, and the biodiesel industry, among others. In addition, the company develops products with technology provided by customers in the fields of pulp and paper, steel, chemicals, mining, and the automotive industry. Dedini has a high vertical integration and is involved in virtually all the stages of construction for a plant/distillery in the sugarcane industry: engineering design, viability study, equipment manufacturing, and plant construction. With approximately four thousand employees, Dedini develops most of the products for plant installations internally. It provides engineering services, assembly design, and viability studies, in addition to producing the equipment, construction and installation, and maintenance services. The company invests in technological development, such as the current project Dedini Rapid Hydrolysis (DHR - Dedini Hidrólise Rápida), which relies on the support of the Foundation for Research Support of the State of São Paulo (Fundação de Amparo à Pesquisa do Estado de São Paulo - FAPESP) and seeks to develop acid hydrolysis to produce ethanol from the cellulose materials of bagasse cane. Zanini, a manufacturer of industrial equipment for the sugar and alcohol sector, was also one of the pillars in forming the current industry for plant equipment and machinery. During the Pro-alcohol program, it grew to seven thousand employees and operated twentyfour hours a day in Sertãozinho. With the end of the Proalcohol program, some companies experienced difficulties and there was restructuring in the sector, including mergers and closings. Zanini teamed up with Renk AG from Germany to form the current Renk Zanini. Today, in Sertãozinho, several companies excel in providing specific solutions for the industry.

An important aspect to be considered is the size of the companies in the two cities. There is greater employment in smaller-sized companies in Sertãozinho compared to Piracicaba, particularly in the mechanical sector. In Sertãozinho, $23 \%$ of workers are employed in companies with less than 49 employees, while in Piracicaba, this share is $16 \%$. Furthermore, in Piracicaba, $38 \%$ of employees in the mechanical sector are employed in companies with more than one thousandemployees, while in Sertãozinho this share is 24\% (IBGE, 2010; Annual List of Social Information - RAIS, 2010). These facts demonstrate that in Piracicaba, the supply of capital goods for the cane alcohol and energy sector gravitates around one large company, Dedini, which has a strong degree of vertical integration. In comparison, in Sertãozinho, there are large companies with a lower degree of integration, leading to the emergence of a large number of small suppliers.

The city of Sertãozinho has one of the largest clusters in the country of suppliers and service providers for the sugarcane-alcohol sector, in addition to the presence of several units from the sugarcane agribusiness. The city has seven plants producing sugar and alcohol and 500 companies in four industrial districts, $90 \%$ of which are focused on the sugar-alcohol industry (CEISE, 2010). This arrangement is the result of a crisis in the sector in the 1990s, with numerous mergers and company closings, which drew skilled labor to the city, and a number of small companies were created to serve the sugar-alcohol sector. The city's industrial capacity is strong: in addition to having one of the largest industrial parks in the state of São Paulo, the city historically developed an arrangement of companies focused on meeting the industrial demand of the sugar industry. The industrial capacity of this LPA allows the companies to develop all the necessary equipment for the installation of a complete plant. Despite advances in the processes and an increased number of products, it is important to note that few companies in the city invest in technology and professional training. The companies essentially respond to the demand of the integrating companies. A large number of the entrepreneurs who own these companies have only technical training from the old Zanini, which was at the forefront of producing and selling to other companies. However, these entrepreneurs are lacking in managerial education, which often results in the loss of valuable opportunities. These entrepreneurs need to invest and change the competitive pattern of their industries.

The proximity of these companies in the informal LPA is one of the main elements of the industry's competitiveness. The fact that the companies are located in the same physical region benefits buyers because they can purchase all the equipment they need in only one visit. Moreover, these companies have developed a way of working together in partnerships, which is very important. They collaborate on sales and develop cooperative projects. Thus, they have a greater competitive advantage compared to the few companies that are not located in the city of Sertãozinho.

\subsection{Efficiency and Innovation}

The equipment industry for the plants was largely responsible for the success of the Brazilian alcohol program because it facilitated processes that enabled significant increases in the conversion rate and thus expanded the 
Brazilian Journal of Operations \& Production Management

Volume 12, Número 2, 2015, pp. 248-256 DOI: 10.14488/BJOPM.2015.v12.n2.a5

potential use of sugarcane. Throughout these years, efficiency gains were incorporated into different stages of the productive process: extraction, the processing of the liquid, fermentation, and distillation. The efficiency standards that were achieved, namely the high maturity of the processes used, made incremental gains difficult for the production of sugar and alcohol in the industrial stage. A study from Copersucar ${ }^{4}$ on plants in the central-south region showed the following indicators for conversion efficiency (Table 1):

TABLE 1

Indicators for conversion efficiency and agricultural productivity.

\begin{tabular}{lcc}
\hline Efficiency & Average & Maximum \\
\hline Extraction - \% & 96.2 & 97.5 \\
Treatment - \% & 99.2 & 99.8 \\
Fermentation - \% & 91.1 & 93.0 \\
Distillation - \% & 99.6 & 99.6 \\
\hline
\end{tabular}

Source: Macedo and Nogueira (2004, p. 12 and 14).

The major changes in industrial efficiency occurred with new technologies (full use of the cane and the development of the hydrolysis process) and the reduction of input consumption (energy and water), particularly in regard to the exchange of equipment that can extend the co-generation of energy. It is important to note that the efficiencies achieved by these companies enabled them to operate in other industries: beverages, paper and cellulose, energy, mining, and oil. Most of these companies are exporters for both sugar and ethanol plants abroad and for other industrial branches.

The companies providing equipment advanced towards turnkey solutions for supplying plants, distilleries, and co-generation systems. The plant is delivered in full working condition and, in some cases, with insurance and performance guarantees. Dedini had already developed plants that integrated biodiesel with ethanol and bioelectricity (three-bio plant). The turnkey packages can be obtained from the companies mentioned above or from engineering companies and contract suppliers that develop the projects. The suppliers have different levels of integration, with some companies that develop almost the entire package and others that contract a larger amount of input from suppliers.

The installation of a complete plant involves the following steps: (Figure 1).

\footnotetext{
${ }^{4}$ Copersucar SA is the biggest trader of Brazilian sugar and ethanol production and integrated to Brazil's biggest exporter of these products, with operations in the main markets worldwide.
}

Figure1 .Industrial capacity.

\begin{tabular}{lll}
\hline \multicolumn{2}{c}{ Industrial Capacity } & \multicolumn{1}{c}{ Industrial Focus } \\
\hline $\begin{array}{l}\text { Design and develop } \\
\text { solutions }\end{array}$ & $\begin{array}{l}\text { Technology } \\
\text { Process engineering }\end{array}$ \\
\hline $\begin{array}{l}\text { Define and specify } \\
\text { solutions }\end{array}$ & $\begin{array}{l}\text { Basic engineering } \\
\text { Equipment engineering }\end{array}$ \\
\hline \multirow{2}{*}{$\begin{array}{l}\text { Execute solutions } \\
\text { Commission }\end{array}$} & $\begin{array}{l}\text { Produce } \\
\text { Install } \\
\text { Assemble }\end{array}$ \\
\hline \multirow{2}{*}{ and } & $\begin{array}{l}\text { Monitoring } \\
\text { Control and performance } \\
\text { Technical assistance }\end{array}$ \\
\hline \multicolumn{2}{c}{ Source: CEISE, 2009. }
\end{tabular}

During the Pro-alcohol program, the national equipment industry supplied 200 complete distilleries in 10 years. For reference, the historical installed capacity is 5 plants/ trimester and 20 per year, with energy co-generation. The capacity for providing installed industry today differs according the order of magnitude of new projects (Table 2):

TABLE 2

Installed supply capacity

\begin{tabular}{ll}
\hline \multicolumn{2}{c}{ Plants by order of magnitude } \\
\hline Typical Solution 1 & Typical Solution 2 \\
$80,000,000$ liters/year of & $180,000,000$ liters/ \\
alcohol & year of alcohol \\
$1,000,000$ tons of cane/ & $2,160,000$ tons of \\
harvest & cane/harvest \\
& $\mathbf{2 4}$ turn-key plants/ \\
$\mathbf{4 0}$ turn-key plants/year & year \\
Lead time 2 years & Lead time 2 years \\
\hline
\end{tabular}

Source: CEISE, 2009

In terms of co-generation, the supply capacity is 40 plants of $30 \mathrm{MW}+1.2 \mathrm{GW} /$ year (CEISE, 2009). Considering the announced investment projects, which include 86 projects by 2012 according to Unica, it appears that the equipment industry is able to meet demand. It is noteworthy that the time between the investment decision and the time when a plant can begin operating is approximately five years. The main determinant for this term is the agricultural phase: the establishment of nurseries for sugarcane and the cane field. Thus, once the investment decision is made, industrial equipment is not the first phase of investment. The construction and installation of a plant is performed during the establishment of the agricultural phase. Thus, no restrictions for equipment suppliers to meet planned investments are observed because the equipment has already been contracted with the supplier. Suppliers already have projects to be delivered over the next decade.

Much of the technology involved in the sector is in the 
public domain. The industry's competitiveness is based mainly on scale (number of people in demand and the size of the production park for sugar and alcohol) and the proximity to consumer markets, which facilitates technical assistance and equipment maintenance.

The specificity of the raw material (sugarcane), which has a defined period for harvesting and a specific interval between the collection and extraction of the juice to prevent a loss of quality, requires the equipment companies to develop an efficient assistance system to attend to the plants in the case of equipment failure. Thus, the proximity of the consumer market is determined, in large part, by the concentration of the equipment sector in Piracicaba and Sertãozinho.

Regarding the productive and technological characteristics of the equipment supply industry, a typology for the companies, which differs according to both the products and the manner in which they work, can be generated (Figure 2):

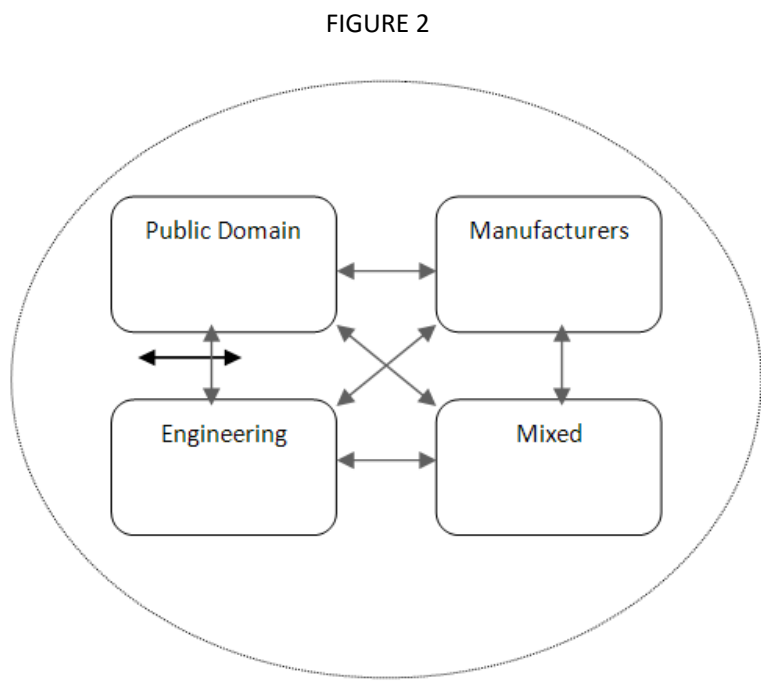

Typology of equipment industries in the sugar-alcohol sector.

The companies in the public domain are the companies that produce low-technology equipment such as tanks, pipes, and chains. These companies acquire the knowhow for equipment and production and do not perform research and development; they are small businesses that are outsourced by the larger companies. The manufacturers are the companies that manufacture equipment that involves more aggregated technology, but they do not have integrated engineering. These companies manufacture the equipment necessary for the implementation of a plant, but they follow the guidelines of an engineering company that develops the projects and the technology necessary for the equipment and the processes. The engineering companies are responsible for research and development in the areas of production and processing technology. These companies sell their projects, acting in partnership with manufacturing companies. The mixed companies manufacture equipment with higher aggregated technology and have an internal research and development center. These companies are responsible for their own projects and also invest in production and processing technology. Generally, mixed companies are focused on producing certain products such as industrial automation.

The companies in this sector, particularly in Sertãozinho, are mostly public domain or manufacturing companies, with fewer mixed companies and engineering companies, which shows that the development of research and technology in these companies is less intense because only a small proportion of the companies fall into this typology. It is noteworthy that despite the low technological intensity, the public domain and manufacturing companies are responsible for diverse incremental innovations in processing and production.

When considering the competitiveness and longevity of this industry, it is important to understand how the profile of public domain and manufacturing companies can be transformed into a profile of companies that invest in research and development. It is not only necessary to characterize the types of companies but also to understand their equipment. There is specific equipment, with varying degrees of technology in development, for each step in the industrial process for the production of sugar, ethanol, and energy (Figure 3).

Figure 3 shows that the equipment manufactured for the industrial process in plants, both for the steps in the production process and for the general equipment, constitutes simple equipment with low technological intensity. Nevertheless, there is still the potential for innovation that will increase productivity gains through equipment or processes.

In general, the equipment industry for the sugarcane sector, which focuses predominantly on metallurgy and mechanics, has low technological intensity. Therefore, there is low investment in research to develop more elaborate technologies.

However, this equipment industry has innovated thWhat is clear is that the industry will have to incorporate investments in research and development so that there is a technological upgrade corresponding to new processes that are designed, as is the case with hydrolysis. The industry will need to stop being reactive because the production of second-generation alcohol will bring a new technological frontier with new characteristics of raw materials, requiring new processes. 
FIGURE 3

Equipment for steps in the production process and potential productivity gains.

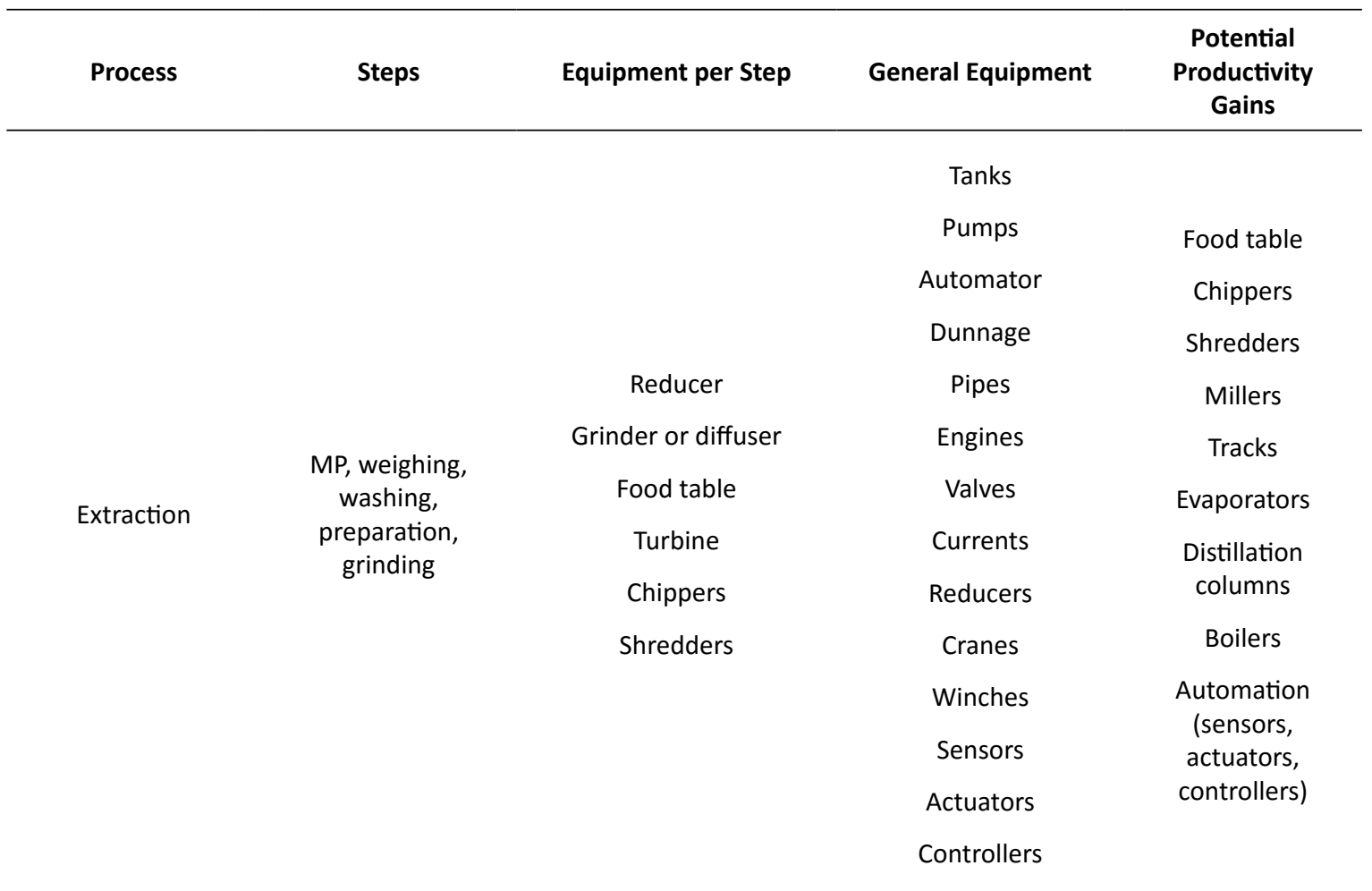

\section{FINAL CONSIDERATIONS}

This study aims to analyze the organization and configuration of the equipment industry for sugar, ethanol, and energy plants. The first point to be noted is the strong growth of this sector due to the expansion of the sugarcane industry, with the emergence of new plants and the expansion and modernization of existing plants. This process has generated strong growth in industrial employment in the cities in which this industry is located. The industry is characterized by national capital and is strongly concentrated in the state of São Paulo, demonstrating the need to be close to the consumer market. The technology is relatively simple and does not constitute a serious barrier to entry for competitors in this segment. Thus, despite the possibility of importing equipment, the practice is quite limited. It is important to note, however, that high currency appreciation in the country has created difficulties for national producers. Growth could be even greater if the country did not have such a high cost of production and allowed plants to accelerate their modernization and technological upgrade programs, replace equipment, and expand energy co-generation.

This sector of equipment producers has not been a barrier to the expansion of the sugarcane and energy sector. However, the growing modernization of the sector will require efforts in the equipment industry to provide the sector with necessary technological advances and possible efficiency gains. Future studies should deepen this discussion on what should be invested in R\&D in this industry and what can be done to encourage such investment. Major searches abroad for new techniques of ethanol production and the prospects of expanding international competition make it imperative that the national equipment supply industry upgrade permanently, create new products, and meet the modifications generated abroad to preserve the country's competitiveness in this sector.

\section{REFERENCES}

Cassiolato, J.E. and Lastres, H.M.M. (2003). O Foco em Arranjos Produtivos e Inovativos Locais de Micro e Pequenas Empresas. In: J.E. Cassiolato, ed. 2003. Pequena Empresa: cooperação e desenvolvimento local. Rio de Janeiro: UFRJ, Instituto de Economia.

Cassiolato, J.E. and Lastres, H.M.M. (2004). Interação, aprendizado e cooperação Tecnológica. Iberoamericana de Indicadores de ciência y Tecnologia. Available through: http:// www.ricyt.org/interior/subredes\%5Cinnova\%5Cdocs/ Cassiolato.pdf. [Accessed 12 March 2010]. 
Centro Nacional das Indústrias do Setor Sucroalcooleiro e Energético. CEISE. Available through: http://www.ceise. com.br. [Accessed 10 December 2009 and 20 January 2010].

Instituto Brasileiro de Geografia e Estatística. IBGE. Ministério do Planejamento, Orçamento e Gestão. Available through: http://www.ibge.gov.br. [Accessed 12 March 2010].

Instituto de Pesquisas Tecnológicas. IPT. Available through: http://www.ipt.br/. [Accessed 20 February 2010].

Jauhar, J. (2008). Políticas Públicas de Implantação de Arranjos Produtivos Locais: a experiência da cerâmica vermelha em Vargem Grande do Sul. Ph.D. Faculdade de Economia, Administração e Contabilidade da Universidade de São Paulo - FEAR-RP. Departamento de Administração.

Macedo, I.C. and Nogueira, L.A.H., 2004. Biocombustíveis. Parcerias Estratégicas. 9(19).

Marshall, A. (1996). Princípios de Economia. La Vergne, TN: Lightning Source.

Ministério da Indústria, Desenvolvimento e Comércio Exterior. MDIC. Available through: http://www. desenvolvimento.gov.br/sitio/interna/index.php?area=1. [Accessed 2 March 2010].

Plonsky, G.A. Serra, N. and Zenha, R.M. (2005). Arranjos Produtivos Locais e o Desenvolvimento Sustentado do Estado de São Paulo. São Paulo, SP: Editora Páginas \& Letras.

Relação Anual de Informações Sociais. RAIS. Ministério do Trabalho e Emprego. Available through: http://www.rais. gov.br. [Accessed 21 February 2010].

Suzigan, W. Furtado, J. Garcia, R. and Sampaio, S. (2003). Sistemas Locais de Produção: mapeamento, tipologia e sugestões de políticas. XXXI Encontro Nacional de Economia. São Paulo, SP. Dezembro, 2003.

Telles, L.O. (2002). Clusters e a Indústria Ligada d̀ Saúde em Ribeirão Preto. Ph.D. Faculdade de Economia, Administração e Contabilidade da Universidade de São Paulo - FEA. Departamento de Economia.

Telles, L.O.; Toneto JR, R. (2007). A Indústria de EMHO em Ribeirão Preto sob a Ótica dos Clusters. Working Paper. Faculdade de Economia, Administração e Contabilidade da Universidade de São Paulo - FEA-RP. Departamento de Economia.

União da Agroindústria Canavieira. UNICA. Available through: http://www.unica.com.br. [Accessed 25 March 2010].

Vicari, F.M. (2009). Uma Proposta de Roteiro para Diagnóstico de Cluster. Ph.D. Escola de Engenharia de São Carlos da Universidade de São Paulo - EESC. Departamento de Engenharia de Produção. 